\title{
ЗАСТОСУВАНННЯ КОМПАРТМЕНТНОГО АНАЛІЗУ ДЛЯ МОДЕЛЮВАННЯ ЕКОЛОГІЧНОГО ВПЛИВУ КОНСОРЦІЙНИХ ЕКОТОНІВ ЗАХИСНОГО ТИПУ
}

\begin{abstract}
Встановлено, що консорційні екотони захисного типу - природні дискретні структурні одиниці рослинного покриву, які мають специфічні властивості. Запропоновано дослідження консорційних екотонів захисного типу за допомогою компартментального аналізу, при цьому ступінь керованості консорційних екотонів захисного типу за допомогою системи блоківкомпартментів залежить передусім від вибраних критеріїв оптимізації. Система критеріїв і субкритеріїв виявляє мету будьякого блоку в системі моделей та основні стратегічні критерії, через які досягають кінцевої мети управлінського процесу. Якщо разом з лінійними типами опису потоків у консорційних екотонах захисного типу кругообіг речовини i/aбо енергії в досліджуваній екосистемі допустити і найпростіший з нелінійних - вольтерівський, то різноманітність можливих режимів поведінки траєкторій у відповідної динамічної моделі природно збільшується. Аналіз таких загальних властивостей цих моделей, як інваріантність невід'ємного конуса, диссипативність системи і стійкість рівноваги в лінійному наближенні, показує, що результати істотно залежать від типу опису. Досліджено, що вихідні потоки енергії можуть бути як відходами досліджуваної системи, так і слугувати ресурсами (вхідними потоками) в іншу систему. На всіх стадіях функціонування консорційних екотонів захисного типу відбувається певне забруднення, використовуються енергія та матеріали. Визначено Есо-індикатор консорційних екотонів захисного типу як замкненої системи матеріальних потоків, відображених у дереві процесів. $E c o$-індикатор є одним із методів, який дає змогу прийняти одну оцінку для всієї системи, враховуючи вхідні та вихідні потоки, а також природно-кліматичні умови - так званий екологічний індекс. Це сума всіх окремих есо-точок, або часткових індексів для всіх процесів, що відбуваються у системі.
\end{abstract}

Ключові слова: консорційні екотони захисного типу; екотони; компартмент; математичне моделювання.

Вступ. Створення мінімальної моделі для консорційних екотонів захисного типу (КЕЗТ) - такої, що агрегує в невеликому числі змінних інформацію про захисні насадження і піддається чисельно-аналітичному дослідженню, є актуальним та важливим завданням в умовах антропогенної трансформації навколишнього природного середовища з боку залізниці. Одним із підходів, що реалізують цю концепцію, $\epsilon$ компартментальний аналіз. КЕЗТ розбивається на блоки, що містять певні запаси речовини й енергії та здатні здійснювати обмін та перенесення не лише між собою, але й з навколишньою природою. На основі біологічної інформації задаються швидкості обміну, а також швидкості вхідних і вихідних потоків. Модель, яку отримуємо, називають компартментною, а блоки - компартментами.

Перевага такого підходу полягає в тому, що, по-перше, немає потреби ретельно збирати дані про взаємодію сотень або тисяч видів, що мешкають у КЕЗТ, а по-друге, дослідник відносно вільний у виборі змінних і предмету обміну (замість біомаси можна оцінювати концен- трацію будь-якого важливого для живих організмів хімічної речовини, зокрема полютантів та седиментів).

Мета дослідження полягає в застосуванні описаного вище алгоритму до розробленої компартментальної схеми КЕЗТ проведено для вивчення екологічного індексу під час моделювання типів міжблокових потоків і динамічних режимів, що виникають за зміни параметрів моделі внаслідок постійно антропогенної дії з боку залізниці.

Матеріали та методи дослідження. Наприкінці 70$\mathrm{x}$ - початку 80 -х років група американських екологів на чолі з Б. Паттеном запропонувала метод аналізу статичних діаграм, який отримав назву енвірон-аналізу (Patten, 1982). Вхідний, або вихідний енвірон (environment навколишнє середовище) цього компартмента - це сукупність блоків, з якими він пов'язаний, що входять або виходять потоками. Використовуючи матричні співвідношення цього методу, можна обчислити, яка частка виходить $3 i$-го компартмента потоку і потрапить в $j$-й, оцінити середній час, що проводиться речовиною в

Інформація про авторів:

Руда Марія Віталіївна, канд. техн. наук, асистент, кафедра екологічної безпеки та природоохоронної діяльності. Email: marichkarmv@gmail.com; https://orcid.org/0000-0003-0590-4589

Гивлюд Анна Миколаївна, канд. техн. наук, асистент, кафедра екологічної безпеки та природоохоронної діяльності. Email: anna.hyvlyud@gmail.com

Лентяков Володимир Валентинович, асистент, кафедра іноземних мов. Email: vlentiakov@gmail.com

Цитування за ДСТУ: Руда М. В., Гивлюд А. М., Лентяков В. В. Застосуванння компартментного аналізу для моделювання екологічного впливу консорційних екотонів захисного типу. Науковий вісник НлТУ України. 2018, т. 28, № 6. С. $60-67$.

Citation APA: Ruda, M. V., Hyvlyud, A. M., \& Lentyakov, V. V. (2018). Application of compartment analysis for modeling of environmental influence of consortium ecotones of protected type. Scientific Bulletin of UNFU, 28(6), 60-67.

https://doi.org/10.15421/40280612 
компартменті, зробити кількісні висновки про роль того чи іншого процесу (наприклад дихання) в житті екосистеми або кругообігу хімічних елементів.

Однак енвірон-аналіз пропонує дослідження лише статичного стану системи, бо однією з його вихідних посилок є сталість потоків і запасів. Але, щоб прогнозувати поведінку екосистеми в часі, потрібно мати ще й динамічну модель. Знання однієї лише діаграми потоків i запасів недостатньо для конструювання динамічної моделі, потрібні розумні додаткові припущення, підкріплені експериментальними фактами, щоб перейти від статичної картини, наприклад до системи КЕЗТ.

Завдання побудови моделі, яка описувала б зміну запасів у часі так, щоб в якийсь момент (або моменти) значення цих змінних і обчислених за ними потоків збігалися із заданою діаграмою, вирішується далеко не од- нозначно. Знизити рівень невизначеності допомагають змістовні уявлення про функціонування реальної системи, для якої будується модель, і природний постулат, що діаграма задає саме рівноважні значення запасів i потоків. Обмежившись певним класом функцій, що описують потоки залежно від поточних значень запасів, і певним типом рівнянь, скажімо, звичайними диференціальними, можна вже однозначно відновити динамічну модель за заданою статичною діаграмою. Конкретну реалізацію такого загального підходу запропонував Ю. М. Свірежев у (Strandberg, 1994).

КЕЗТ складається $3 n$ компартментів, пов'язаних між собою потоками речовини $f_{k i}$ (з $k$-го в $i$-й), кожен блок може приймати 3 навколишнього абіотичного середовища або інших екосистем потік $q_{i}$, а віддавати потік $y_{i,}$ як показано на рис. 1.

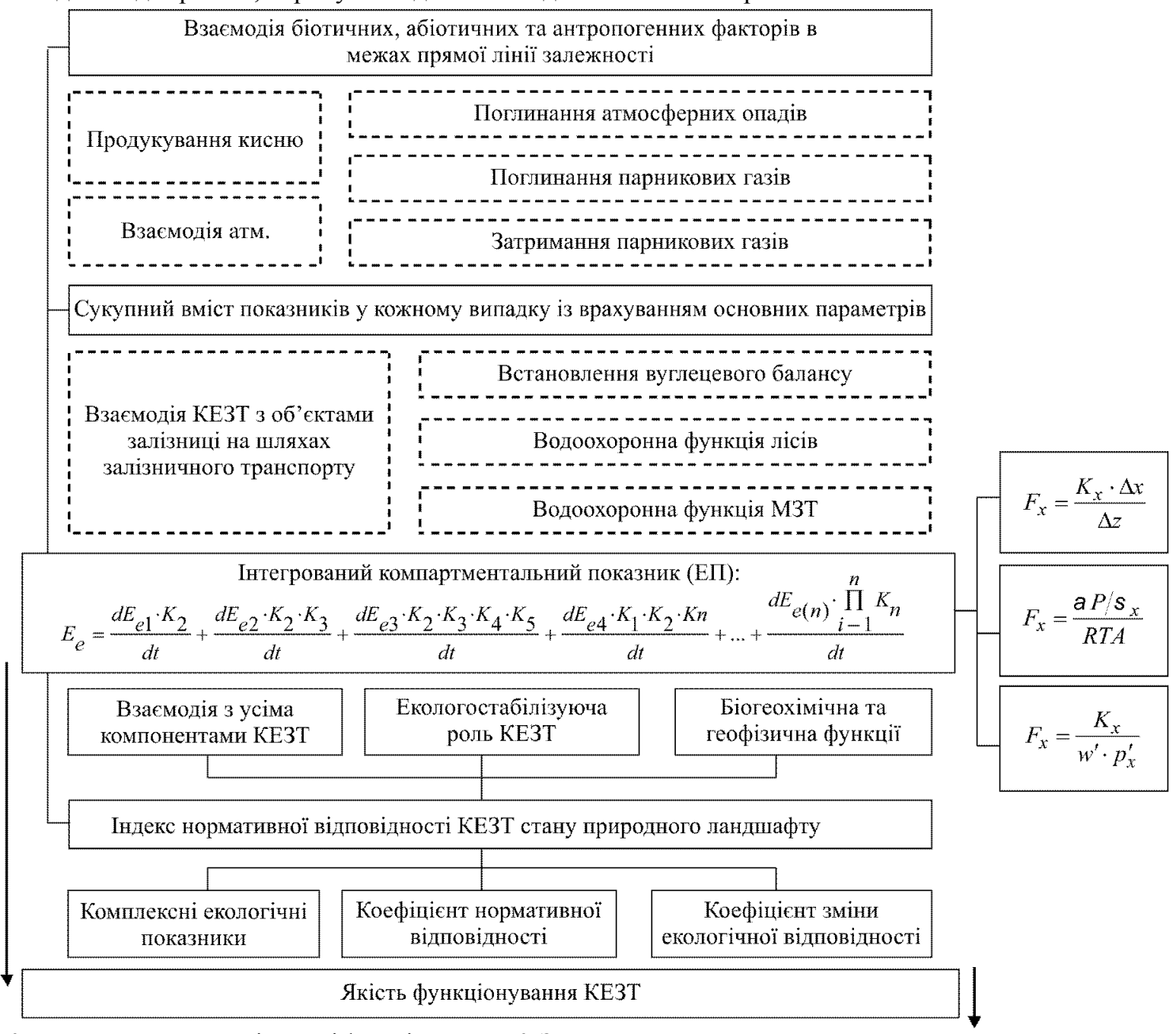

Рис. 1. Компартментальний аналіз якості функціонування КЕЗТ

Ступінь керованості КЕЗТ за допомогою системи блоків-компартментів залежить насамперед від вибраних критеріїв оптимізації (див. рис. 1). Система критеріїв і субкритеріїв виявляє мету будь-якого блока у системі моделей та основні стратегічні критерії, через які досягається кінцева мета управлінського процесу.

Якщо разом з лінійними типами опису потоків в КЕЗТ кругообіг речовини i/або енергії в досліджуваній екосистемі допустити і найпростіший 3 нелінійних вольтерівський, то різноманітність можливих режимів поведінки траєкторій у відповідної динамічної моделі природно збільшується. Аналіз таких загальних властивостей цих моделей, як інваріантність невід'ємного ко- нуса, диссипативність системи і стійкість рівноваги в лінійному наближенні, показує, що результати істотно залежать від типу опису.

Особливо зручною у практиці екологічного моделювання $\epsilon$ можливість обчислення Якобіана системи рівнянь безпосередньо за цими діаграмами, минаючи етап виписування самих рівнянь. Тут відкривається шлях вивчення i порівняння самих діаграм у термінах стійкості відповідних матриць. В умовах невизначеності, яка часто супроводжує етап розроблення концептуальної схеми моделі, подібна додаткова інформація має певну цінність. 
Результати дослідження та їх обговорення. КЕЗТ природні дискретні структурні одиниці рослинного покриву, які мають специфічні властивості, зокрема здатність захищати навколишнє середовище від шуму, шкідливих речовин тощо, а залізничну колію - від снігу, вітру, дії інших природно-кліматичних факторів. КЕЗТ - територіально єдина ділянка лісонасадження, яка має прямокутну або близьку до неї форму (рис. 2). У конструкція КЕЗТ керівними параметрами, зокрема, є:

- вертикальна структура, яка задається ярусами (ярус домінуючих дерев; середній ярус; чагарниковий ярус; мохово- трав'яний ярус; ярус залягання кореневищ i коренів трав'яних рослин, що укореняються у верхньому шарі грунту - 15-20 см; ярус трав'яних рослин із глибшим розташуванням коренів - 50-70 см; ярус коренів чагарників - 1-3 м; ярус коренів деревних порід (Н - до 5-6 м), лісова підстилка (H - 1-3 см); гумусовий горизонт ( $\mathrm{H}-20 \mathrm{~cm}-1,5 \mathrm{м})$; горизонт вимивання, або накопичення $(\mathrm{H}-0-20 \mathrm{~cm})$; перехідний горизонт (Н - до 180 см;).

- горизонтальна структура: кількість рядів, ширина рядів, розміщення дерев у рядах та кулісах, кількість куліс тощо.

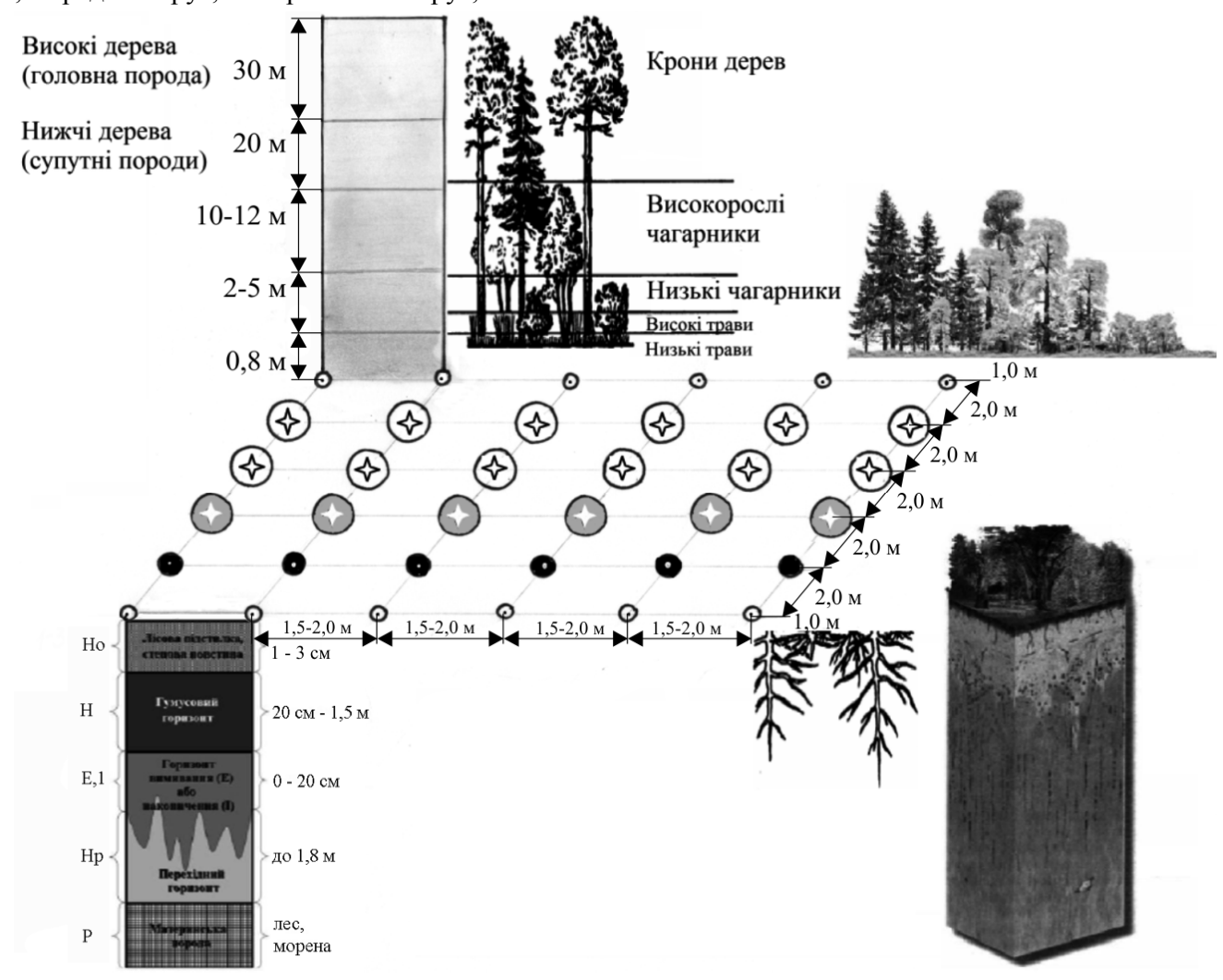

Рис. 2. Схема КЕЗТ на шляхах залізничного транспорту

КЕЗТ є замкненою системою матеріальних потоків (на противагу енергетичним потокам). Переходячи з одного продукту в інший та змінюючи форми свого стану, матерія циклічно циркулює в цій системі. Саме тому загальна маса матерії не змінюється, незалежно від того, що відбувається на шляхах залізничного транспорту.

У сучасному соціально-економічному середовищі матеріальні потоки і процеси відбуваються за лінійною схемою. Але на нескінченному відрізку часу матеріали, що пройшли через техносферу, заново повертаються у навколишнє середовище як сировина.

Вихідні потоки енергії можуть бути як відходами досліджуваної системи, так і слугувати ресурсами (вхідними потоками) в іншу систему. На всіх стадіях функціонування КЕЗТ відбувається певне забруднення, використовуються енергія та матеріали.

Під час математичного моделювання в КЕЗТ будемо розглядати їх екологічний вплив як деякий індекс, який приймається однорідним і ізотропним у горизонтальній площині, а площа екотонів захисного типу (ЕЗТ) - досить велика для того, щоб можна було зневажити ефектом "краю поля". У цьому випадку всі перетоки енергії і речовини здійснюються тільки у вертикальному напрямку. Більш того можна також нехтувати ефектом неоднорідності грунту, вважаючи, що описувані процеси можуть бути віднесені до будь-якої частини ЕЗТ, або до КЕЗТ загалом. Зрозуміло, однорідних й ізотропних ЕЗТ у природі не існує, а прийнята ідеалізація - це та данина, яку треба платити за суворість математичних побудов. Неоднорідність моделяційної системи виявляється при цьому тільки у вертикальному напрямку: у кожний момент часу існує деякий розподіл фітоелементів за висотою КЕЗТ і за глибиною грунтового профілю.

Виділимо деяку ділянку КЕЗТ одиничної площі. За умовами, усі такі ділянки еквівалентні. Проведемо верхню межу досліджуваної системи паралельно до поверхні грунту на висоті $H$, приблизно рівній потроєній висоті дерев $h$. На деякій глибині $R$ за межами шару розміщення кореневої системи проведемо нижню грань. Утворений в такий спосіб паралелепіпед і будемо розглядати як об'єкт моделювання (рис. 3). Оскільки через бокові грані обмін енергією і речовиною не відбувається, то у виділений об'єм проникає зверху сонячна радіація і вуглекислий газ, а через верхню грань видаляються, наприклад, пари води. Точно так само означені обмінні процеси відбуваються на нижній грані. При цьому все, що надходить у систему, належить до ії вхідних впливів, а все, що з неї видаляється, - або до втрат, або до відчужуваного кінцевого продукту. 


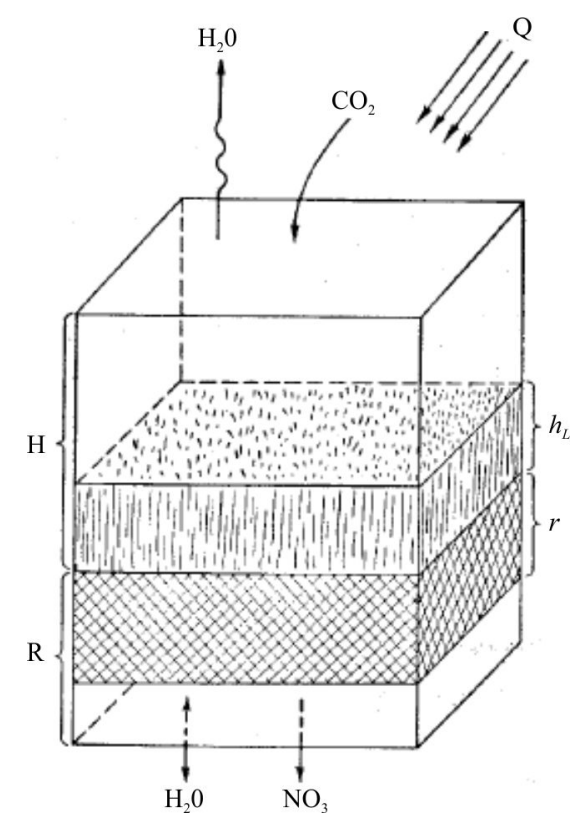

Pис. 3. Схематичне зображення ЕЗТ як об'єкта моделювання: $h_{L}$ - висота посіву; $r$ - глибина проникнення коренів

Позначимо спрямовану вгору вертикальну координату через $x$, помістивши іiї початок (точку 0 ) на поверхні грунту. Час позначимо через $t$. У такому випадку всі змінні моделі будуть залежати від двох аргументів $x$ i $t$. У кожен момент часу у системі існуе вертикальний розподіл характеристик рослинного покриву, а також різних субстанцій - води у грунті, іонів амонію і нітратів у грунтовому профілі, температури грунту, забруднення полютантами та седиментами і т. ін. У надземній частині системи також існує вертикальний розподіл різних параметрів - антропогенного забруднення, радіації, температури і вологості повітря, температури листя, концентрації вуглецю та азоту у фітоелементах і т. ін. (рис. 4). Під дією сил різної природи ці величини змінюються.

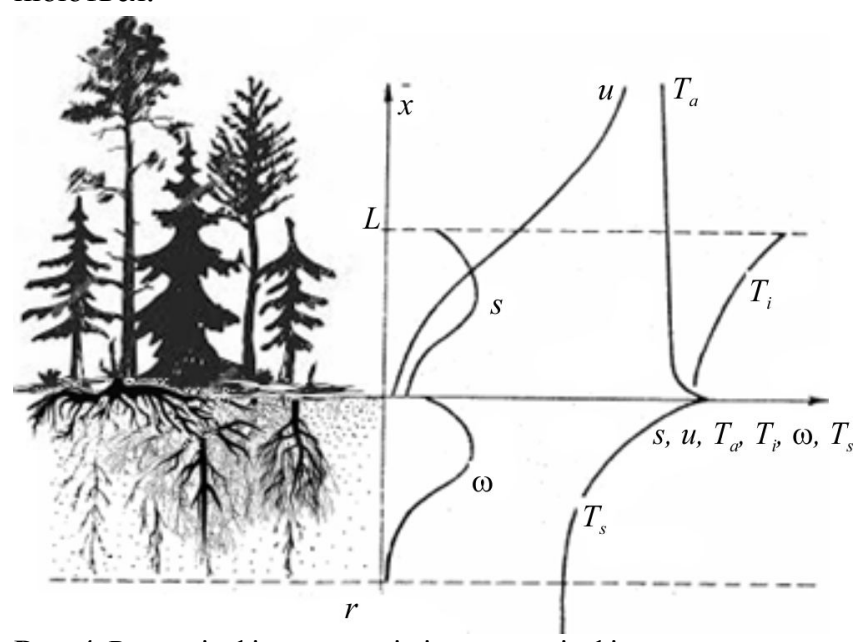

Рис. 4. Розподіл фітоелементів і параметрів фітосередовища: s - об'ємна щільність листкової поверхні; $\omega$ - об'ємна щільність поглинальної поверхні коренів; $\mathrm{u}$ - швидкість вітру; $\mathrm{T}_{\mathrm{a}}, \mathrm{T}_{\mathrm{i}}, \mathrm{T}_{\mathrm{s}}-$ температура повітря, листя і грунту відповідно

Основним завданням $є$ опис цих змін, тобто процесів вертикального енерго- і масообміну в системі, фізико-хімічних перетворень і біологічних трансформацій компонентів системи, а також фізіологічних процесів у рослинах, які призводять до їхнього росту, розвитку, а в деяких випадках - до хвороб та загибелі під дією забруднення.
Подальша деталізація опису розглянутого підходу пов'язана з необхідністю введення поняття компартментних моделей. Компартмент (від франц. compartementвідсік, купе) є елементарним функціональним елементом моделі. Він характеризується мінімальним об'ємом і поточним складом відповідної субстанції. Оскільки розглядаються тільки вертикальні потоки, виділення компартментів у системі пов'язано з іiі вертикальною стратифікацією.

Для прикладу, розділимо грунтовий профіль на деяку кількість шарів малої товщини $\Delta x$ так, щоб кожен шар можна було приблизно вважати однорідним. Перенумеруємо ці шари зверху вниз і розглянемо шар з номером $i$ (див. рис. 4). Баланс кожного компонента моделі в $i$-му компартменті складається 3 трьох складових: обмін з розташованим нижче компартментом, обмін 3 розташованим вище компартментом, перетворення енергії або речовини всередині компартмента в іншу форму.

Так, зміни вологозапасів у компартменті за один часовий крок моделі $\Delta W i$, визначають за виразом

$$
\Delta W i=V_{i+1}-V_{i}-f_{i},
$$

де: $V_{i+1}-$ потік вологи 3 розташованого нижче шару грунту; $V_{i}$ - потік вологи у сусідній шар, розташований вище від даного; $f_{i}$ - поглинання води коренями, розташованими у даному шарі.

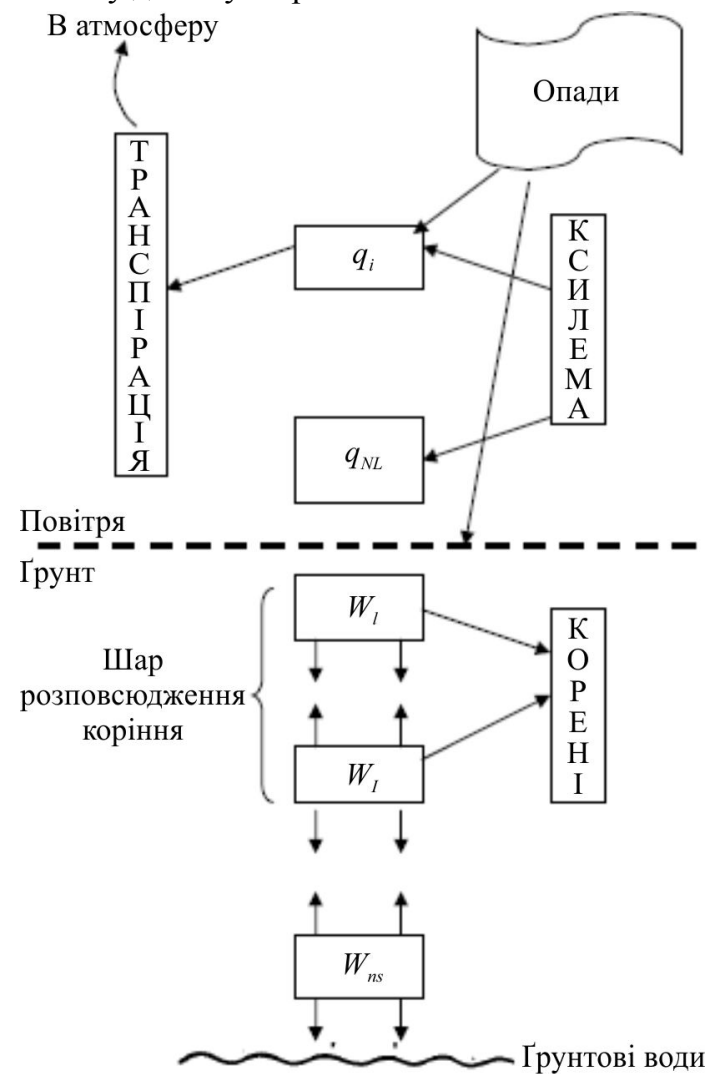

Рис. 5. Компартментна схема вологоперенесення у системі грунт - рослина - атмосфера: $\mathrm{W}_{\mathrm{i}}$ - вологовміст в і-му компартменті грунту; $\mathrm{q}_{\mathrm{i}}$ - вологість повітря у міжклітиннику; NS кількість шарів грунту; $\mathrm{NL}$ - кількість ярусів посіву

Максимальна ємність компартмента часто не є величиною постійною. Для води максимальна ємність дійсно визначається вільним поровим простором грунту. А для полютантів та седиментів ця величина визначається насичувальною концентрацією і залежить від вологовмісту. Об'єм пор, який може зайняти грунтове повітря, також визначається вологістю грунту, а для 
теплоємності явне значення верхньої межі взагалі відсутнє. На рис. 5 наведено повну компартментну схему для вологоперенесення у системі грунт - рослина - атмосфера. 3 розглянутого виходить, що повну компартментну схему для КЕЗТ на шляхах залізничного транспорту навряд чи можна зобразити на одному рисунку і представляти її потрібно, очевидно, лише поблоково.

Наведене вище трактування означає просторову дискретизацію неперервної системи. Це, очевидно, пов'язано з тим, що модель реалізується на цифрових машинах, які є обчислювачами дискретної дії. Не менш важливим є питання часової дискретизації, тобто питання вибору кроку розрахунку моделі за часом. Ситуація тут аналогічна. Дроблення часового кроку збільшує точність, але подовжує час прогону моделі. У наявних динамічних моделях величина часового кроку змінюється від хвилин (іноді частки хвилин) до доби. Добовий крок мають прості прикладні моделі. У базових моделях багато процесів повинні розраховуватися 3 кроком в одну годину або декілька хвилин. Величина часового кроку тісно пов'язана із кроком просторової дискретизації. Окрім цього, вона може бути перемінною протягом одного прогону моделі.

Результати дослідження та їх обговорення. Для визначення екологічного індексу КЕЗТ, використовуючи компартментний підхід до моделювання, потрібно здійснити три частини аналізу: інвентаризаційну $\rightarrow$ екологічного впливу $\rightarrow$ можливостей поліпшення. Усі три частини дослідження взаємопов'язані через етап формулювання задачі та встановлення меж досліджуваної системи. Формулювання завдання є важливим етапом, що становлять основу всього моделювання.

Формулювання завдання - це особливо важлива стадія моделювання, оскільки на ній визначається зміст і порядок виконання всіх подальших стадій. Для формулювання завдання потрібно відповісти на питання "для якої мети проводиться моделювання?". Для цього нам потрібно: знати, яка саме система аналізується; переконатися, чи можна порівняти систему за їі функціями; знати, хто і як буде користуватися отриманими результатами аналізу; чітко визначити, за якими параметрами буде проводитися аналіз; встановити причини, за якими для порівняння були обрані саме ці параметри (параметри повинні бути репрезентабельними, тобто відповідати цілям аналізу); визначити призначення системи і функціональну одиницю, використану для аналізу; визначити масштаб і глибину проведеного аналізу, або, іншими словами, визначити межі модельованої системи.

Останній аспект найважливіший, тому що вибір меж системи визначає тривалість, складність, точність і повноту результатів моделювання.

Межі системи - це стадії та елементи енергетичного балансу, які розглядаються в аналізі життєвого циклу продукту/послуги (Dejli, 2002). Межі також включають відповідний проміжок часу, географічні координати системи, тип технології, яка використовується на цей момент, а також набір аналізованих параметрів впливу на довкілля (Mirchulava, 2001).

Важливо обмежувати межі системи для забезпечення прийнятного рівня точності результатів. По-перше, обмежувати аналізовану систему потрібно тому, що система без обмеження може розростися до неймовірних розмірів. По-друге, аналізована система не може бути занадто простою, тому що можливе упущення ок- ремих складових життєвого циклу, що здійснюють істотні екологічні впливи. У такому випадку результат аналізу буде неточним.

Якість функціонування певною мірою визначає функціональну одиницю, яка $\epsilon$ одним 3 найголовніших аспектів, що впливають на якісні розрахунки. Під функціональною одиницею розуміємо кількісний вираз функції системи, яка відображає характеристики аналізованих систем. Функціональна одиниця - це основа для всіх наступних розрахунків, вся інформація, зібрана на стадіях інвентаризації та оцінки впливів, належить до функціональної одиниці.

Інвентаризаційний аналіз - це фаза, призначена для збирання кількісних даних, що характеризують весь життєвий цикл. На цьому етапі ідентифікуються й аналізуються всі потоки (входи/виходи) системи, які розміщені в обраних межах системи. Потоки системи можуть бути розділені на потоки матерії (сировина, продукти, відходи) і потоки енергії. Дані збираються в таблиці, які називають інвентарними профілями.

Після збору кількісної інформації про матеріальні та енергетичні потоки системи останні оцінюють 3 екологічної точки зору. Оцінювання екологічного впливуце стадія, на якій дані про різні викиди у довкілля, зібрані на стадії інвентаризації, характеризуються і оцінюються в різних групах і за різними параметрами. Іншими словами, встановлену кількість викидів інтерпретують у вигляді нанесеного екологічного збитку.

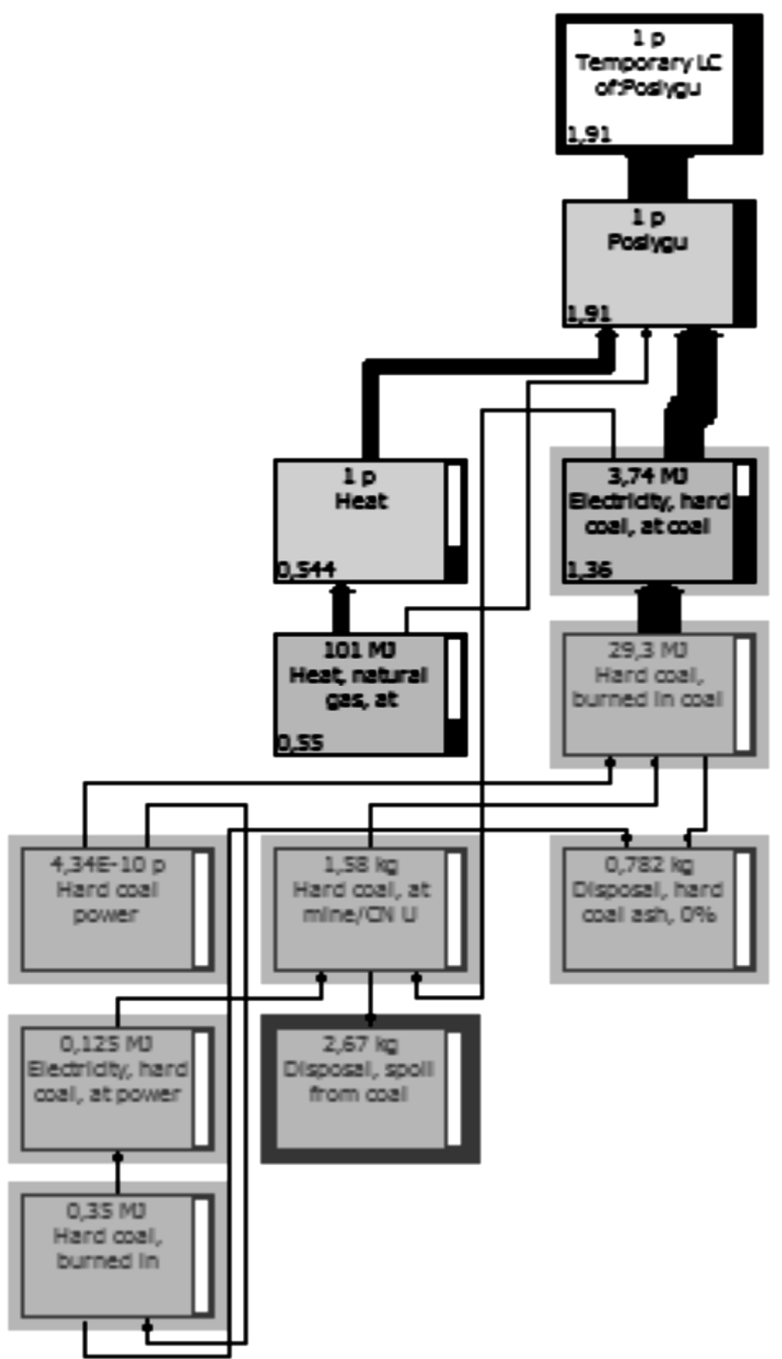

Рис. 6. Дерево процесів якості функціонування КЕЗТ на шляхах залізничного транспорту 
Для аналізу якості функціонування КЕЗТ на шляхах залізничного транспорту було згруповано необхідні дані, а саме: основні ресурси, що потрібні для функціонування КЕЗТ та залізничних шляхів, комплектуючі кожної складової сировини та матеріалу, які розглядаються як входи; процеси, такі як транспортування людей та вантажів, в тому числі і небезпечних, природно-кліматичні умови (виходи). Для зручності з роботою складові частини процесу було згруповано у дві групи: необхідні природні ресурси; технічні та технологічні засоби.

Поступово до програми SimaPro, яка є професійним інструментом для збору, аналізу та моніторингу екологічних характеристик складних, полікомпартментних систем, до яких відносимо і КЕЗТ, заносились дані про окремі частини процесу із зазначенням складових матеріалів, компонентів і процесів, що їх супроводжували.

На основі проведеного енергетичного балансу КЕЗТ будуємо дерево процесів для виявлення слабких точок аналізу (рис. 6). Такий аналіз дає змогу розрізняти важливі і менш важливі процеси (виявити "гарячі точки").
У нашому випадку "гарячими точками" є втрати, що пов'язані з анторопогенним впливом на стан КЕЗТ рухомим складом залізниці. На рис. 7 також чітко простежується і позитивна тенденція - затримання полютантів та седиментів КЕЗТ на шляхах залізничного транспорту. На згаданому рисунку (див. рис. 6) товщина лінії відображає навантаження процесу на довкілля за системою Eco-indicator 99. Відображений на цьому рисунку також інтегрований показник - екологічний індекс, виражений в екобалах. Така можливість дає змогу порівнювати різні за своєю структурою процеси, що містять відмінність в енергетичних балансах, проте використовують один і той самий набір (входів) компонентів навколишнього природного середовища.

Після завершення побудови дерева провели аналіз оцінки впливів на довкілля. Процес аналізу складався 3 таких п'яти елементів: характеризація $\rightarrow$ оцінювання шкоди $\rightarrow$ нормалізація $\rightarrow$ зважування $\rightarrow$ визначення екологічного індексу.

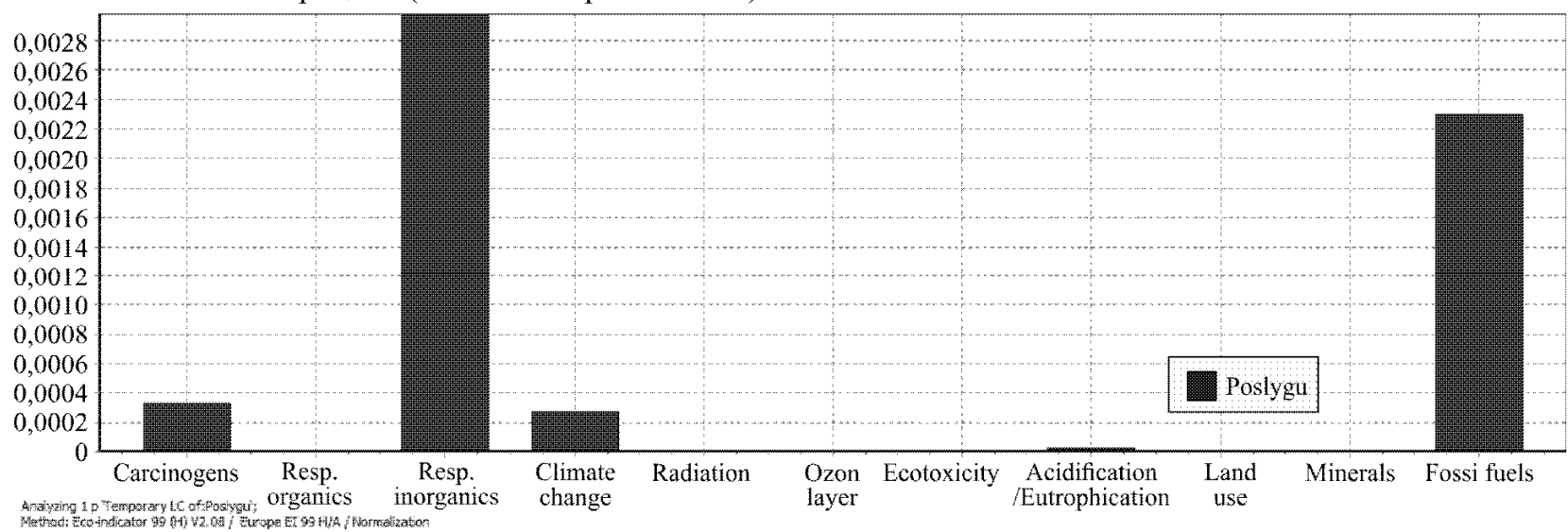

Рис. 7. Оцінка впливів на КЕЗТ з боку рухомого складу залізниці

Наступним кроком стало продовження аналізу на основі "характеризації". Це групи входів і виходів, які розподіляються між одинадцятьма категоріями впливу відповідно до методології Eco-індикатора 99. Характеризація показує відносну силу небажаних впливів, кожен з відповідним матеріалом життєвого циклу у визначенні питомої ваги: канцерогенів, респіраторних речовин, змін клімату, радіації, впливу на озоновий шар, еко-токсичність, викопних видів палива, змін у землекористуванні, мінералів, підкислення/евтрофікації. Усі від'ємні значення потрапляють у сферу функціонування КЕЗТ, і представляють собою заходи із запобігання викидам шкідливих речовин, тому ці значення свідчать про позитивні, бажані з точки зору стану навколишнього природного середовища процеси, тобто говорять про те, що речовини вловлюються.

Як обчислювальні процедури, які використовуються для агрегування даних у впливі категорій, застосовуються екологічні моделі для порівняння різних внесків у ті ж екологічні проблеми. Це завдання може бути досягнуто за допомогою еквівалентності факторів, передбачених моделями (рис. 8).

3 цього графіка бачимо характерні результати специфікації, що свідчить про те, що у деяких категоріях впливів домінує вплив рухомого складу залізниці, проте він не применшує значення якісних показників функціонування КЕЗТ, усі впливи відображені на 100 \%-й шкалі, кольори демонструють внесок кожного елемента.

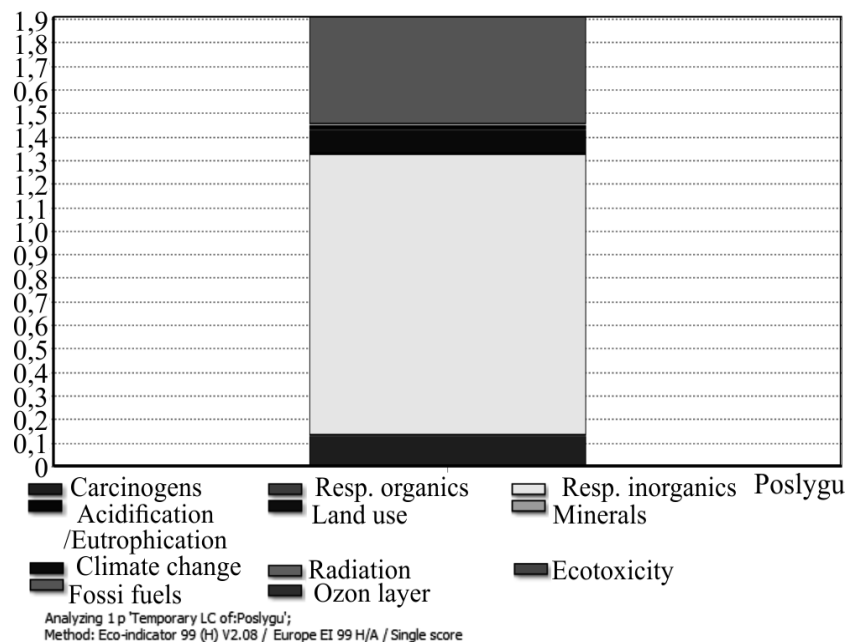

Рис. 8. Екологічні моделі внесків у якість функціонування KE3T

Аналогічно можна оцінити впливи на довкілля на таких етапах аналізу: оцінка збитків $\rightarrow$ нормалізація $\rightarrow$ зважування $\rightarrow$ визначення екологічного індексу.

Для отримання практичніших результатів можна всі впливи об'єднати у три категорії, а саме: здоров'я людини (канцерогени; респіраторні речовини; зміна клімату; радіація; озоновий шар; еко-токсичність); якість КЕЗТ (стан грунту; життєздатність); природні ресурси (мінерали; викопні види палива). 
На рис. 9 бачимо, що найбільший вплив від газопостачання, враховуючи і забруднення повітря, здійснюється на природні ресурси та здоров'я людей.

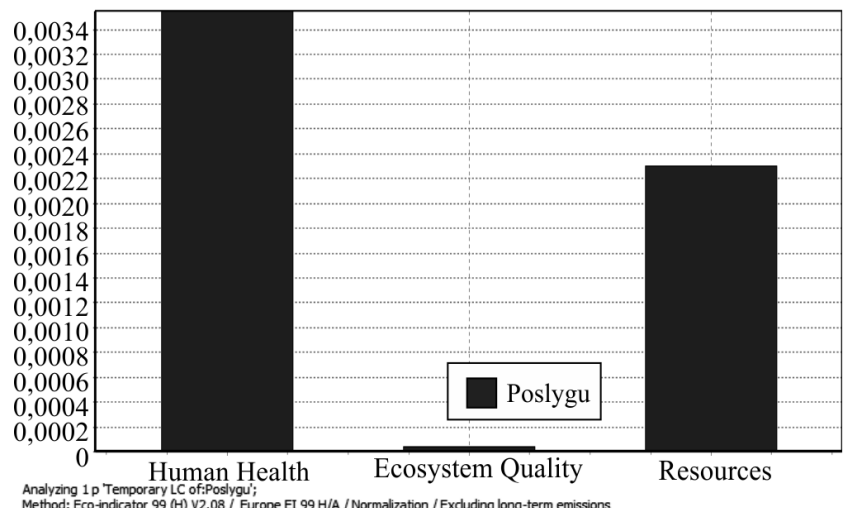

Рис. 9. Оцінка впливу на компоненти довкілля

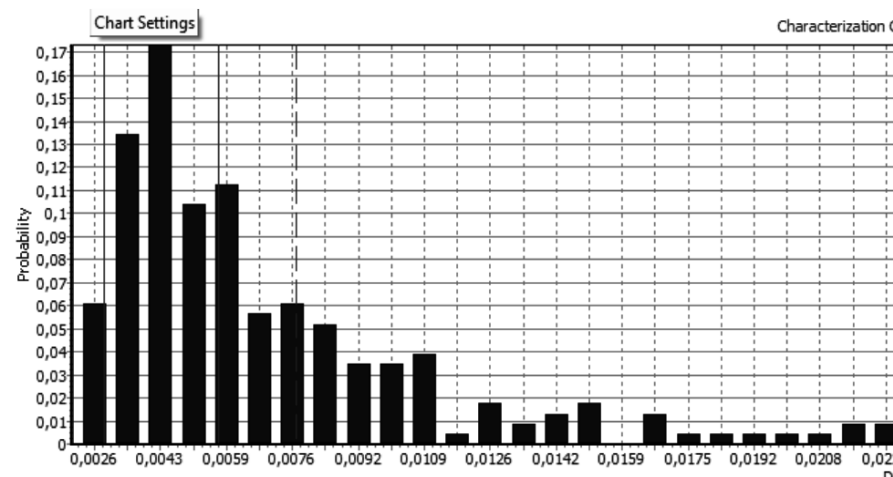

Uncertainty analysis of 1p 'ife Cyde__as',

Рис. 10. Визначення екологічного індексу

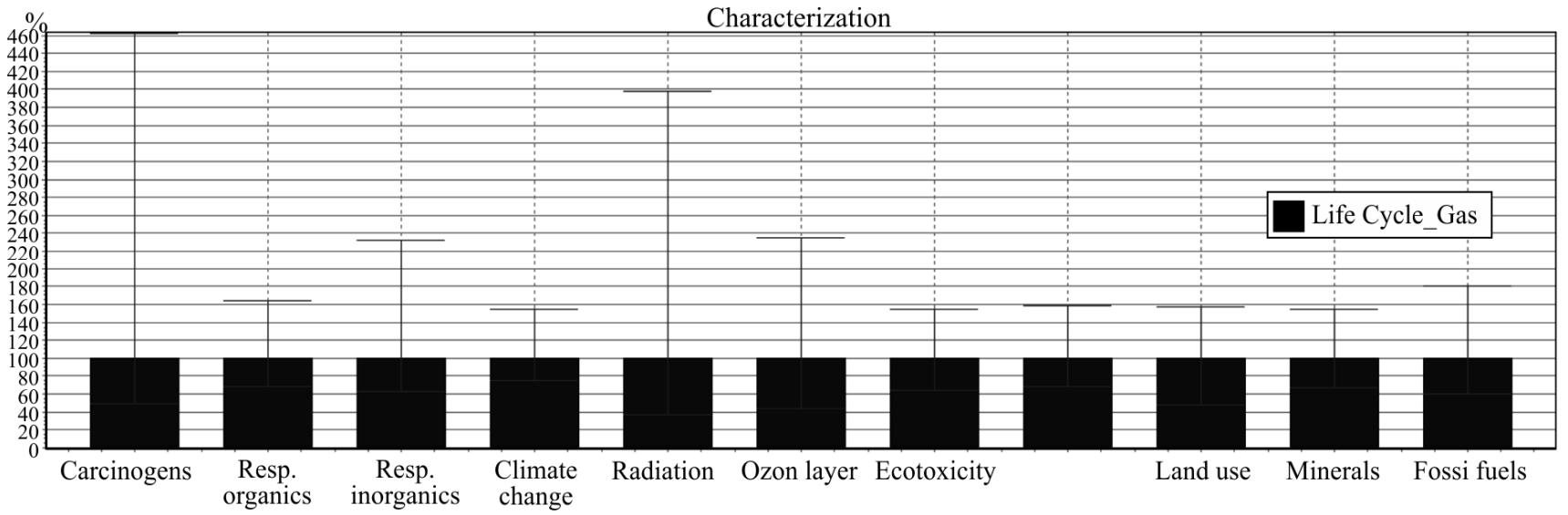

Рис. 11. Визначення екологічних слідів системи

Висновки. Запропоновано підхід до дослідження КЕЗТ за допомогою компартментального аналізу, при цьому ступінь керованості КЕЗТ за допомогою системи блоків-компартментів залежить насамперед від вибраних критеріїв оптимізації. Система критеріїв і субкритеріїв виявляє мету будь-якого блоку в системі моделей та основні стратегічні критерії, через які досягається кінцева мета управлінського процесу.

Чисельним виразом пропонованого підходу є визначення Eco-індикатора КЕЗТ як замкненої системи матеріальних потоків, відображених у дереві процесів. Ecoіндикатор дає змогу прийняти одну оцінку для всієї системи, враховуючи вхідні та вихідні потоки, а також природно-кліматичні умови - так званий екологічний
$E c o$-індикктор $99 є$ одним із методів, який дає змогу прийняти одну оцінку для всієї системи, враховуючи вхідні та вихідні потоки, а також природно-кліматичні умови - так званий екологічний індекс. Це сума всіх окремих есо-точок або часткових індексів для всіх процесів, що відбуваються. Обчислювальна процедура здійснюється шляхом підсумовування результатів зважування фаз життєвого циклу. На рис. 10 наведено остаточні результати якості функціонування КЕЗТ на шляхах залізничного транспорту.

Екологічний індекс становить у нашому випадку1,91. Для цього процесу було прораховано також і екологічні сліди, що можуть виникати в майбутньому (рис. 11). На основі отриманих даних можна формувати рекомендації для покращення функціонування КЕЗТ на шляхах залізничного транспорту. erization Carcinogens

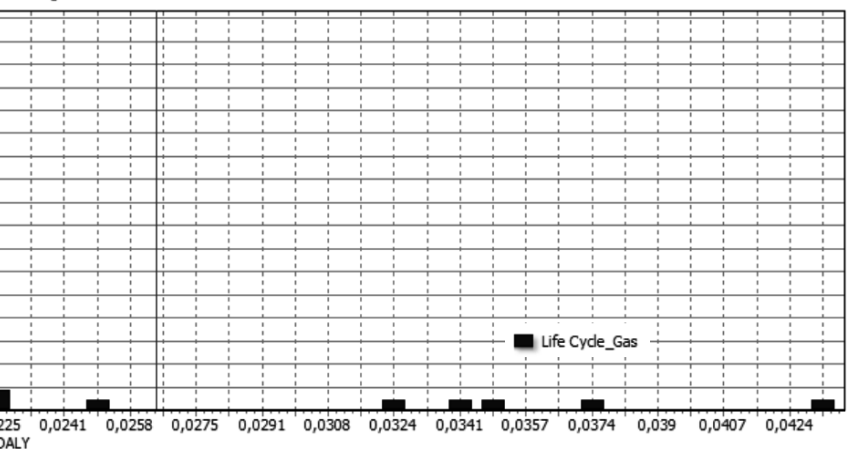

DALY 


\title{
ПРИМЕНЕНИЕ КОМПАРТМЕНТНОГО АНАЛИЗА ДЛЯ МОДЕЛИРОВАНИЯ ЭКОЛОГИЧЕСКОГО ВЛИЯНИЯ КОНСОРЦИОННЫХ ЭКОТОНОВ ЗАЩИТНОГО ТИПА
}

\begin{abstract}
Доказано, что консорции экотонов защитного типа - природные дискретные структурные единицы растительного покрова, которые имеют специфические свойства. Предложено исследовать консорции экотонов защитного типа с помощью компартментального анализа, при этом степень управления консорциями экотонов защитного типа с помощью системы блоков-компартментов зависит в первую очередь от выбранных критериев оптимизации. Система критериев и субкритериев обнаруживает цель любого блока в системе моделей и основные стратегические критерии, через которые достигается конечная цель управленческого процесса. Если вместе с линейными типами описания потоков в консорциях экотонов защитного типа круговорот вещества и/или энергии в исследуемой экосистеме допустить и самый простой из нелинейных - вольтеровский, то разнообразие возможных режимов поведения траекторий соответствующей динамической модели естественно увеличивается. Анализ таких общих свойств этих моделей, как инвариантность неотъемлемого конуса, диссипативность системы и устойчивость равновесия в линейном приближении, показывает, что результаты существенно зависят от типа описания. Доказано, что выходные потоки энергии могут быть как отходами исследуемой системы, так и служить ресурсами (входящими потоками) в другую систему. На всех стадиях функционирования консорции экотонов защитного типа имеет

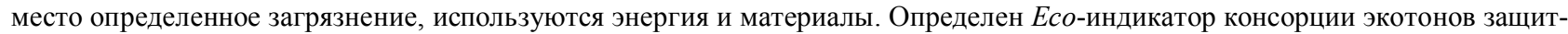
ного типа как замкнутой системы материальных потоков, отраженных в дереве процессов. Есо-индикатор является одним из методов, который позволяет принять одну оценку для всей системы, учитывая входные и выходные потоки, а также природно-климатические условия - так называемый экологический индекс. Это сумма всех отдельных есо-точек или частичных индексов для всех процессов, имеющих место в системе.
\end{abstract}

Ключевые слова: консорции экотонов защитного типа; экотон; компартмент; математическое моделирование.

M. V. Ruda1, A. M. Hyvlyud1, V. V. Lentyakov²

Lviv Polytechnic National University, Lviv, Ukraine

${ }^{2}$ Ukrainian National Forestry University, Lviv, Ukraine

\section{APPLICATION OF COMPARTMENT ANALYSIS FOR MODELING OF ENVIRONMENTAL INFLUENCE OF CONSORTIUM ECOTONES OF PROTECTED TYPE}

Consortium ecotones of protective type are defined to be natural discrete structural units of plant cover, which have specific properties. The research of the consortium ecotones of the protective type applying the compartmental analysis are proposed, while the methods of the protection of consortium ecotones of the protective type with respect to the system of block-compartments depends mostly on the choice of optimisation methods. The system of criteria and subcriteria detects the purpose of any block in the system of models and the main strategic criteria through which the ultimate objective of management process is met. If we allow the circulation of substances and/or energy within the investigated ecosystem both the linear types of flow description in the consortium of protective ecotones and the simplest non-linear, then the range of possible modes of trajectories behavior of a certain dynamic model increases naturally. In addition, it is possible to insert a non-intrusive word into an infinite number of characters, to disclose the secrets of a particular expression in the immediate vicinity, which suggests that it should be distinguished from a typical oppression. It is researched that the exhausting energy flows can be both from the exits of the investigated system and serve as resources (extraneous flows) to another system. For all stages of the functioning of conservative protective ecotones there is certain pollution, using energy and materials. The Eso-indicator of the consortium protective ecotones as the closed system of material flows reflected in the process tree is determined. The Eco-indicator is one of the methods that allows estimating one criterion for the whole system, verifying extraneous and outflow flows, as well as natural and climatic conditions, the so-called ecological index. This is the sum of all individual eco-points or partial indexes for all the processes occurring in the system.

Keywords: consortium protective ecotones; ecotones; compartment; mathematical modeling. 